\title{
Long-term change of mass balance and the role of radiation
}

\author{
Atsumu OHMURA, ${ }^{1}$ Andreas BAUDER, ${ }^{2}$ Hans MÜLLER, ${ }^{3}$ Giovanni KAPPENBERGER ${ }^{4}$ \\ ${ }^{1}$ Institute for Atmospheric and Climate Science, Swiss Federal Institute of Technology (ETH), CH-8092 Zürich, Switzerland \\ E-mail: ohmura@env.ethz.ch \\ ${ }^{2}$ VAW, Swiss Federal Institute of Technology (ETH), CH-8092 Zürich, Switzerland \\ ${ }^{3}$ Tergeso AG, Stadterwingert 4, CH-7320 Sargans, Switzerland \\ ${ }^{4}$ Swiss Meteorological Institute, CH-6605 Locarno-Monti, Switzerland
}

\begin{abstract}
The effect of climate change in the 20th century is investigated based on measured massbalance data. Annual, winter and summer mass balances on Claridenfirn, Switzerland, (since 1914/15) Storglaciären, Sweden, (since 1945/46) Storbreen, Norway, (since 1948/49) Glacier de Sarennes, France, (since 1948/49) and Vernagtferner, Austria, (since 1965/66) are studied with air temperature at high-altitude stations and the longest records of solar global radiation in Europe. The mean mass balances of these glaciers during the 20th century were mostly negative except for the first two decades. The fluctuating mass balance reaches the minimum (largest loss) and maximum (almost equilibrium) around 1940 and 1980, respectively, with a drastic loss in the last 15 years. These variations are mostly steered by the variation in summer mass balance. The change in the summer mass balance is determined to $72 \%$ by temperature and the remaining $28 \%$ by solar radiation. During the colder period (e.g. 196080 ), the reduction in solar radiation counteracted the warming trend due to the greenhouse effect. Since 1990 the greenhouse effect of terrestrial radiation and the global brightening effect of solar radiation have both been acting to accelerate the melt, resulting in the unprecedented mass loss of the observational era. The glacier mass balance during the 20th century clearly reacted towards temperature and solar radiation changes, which reflected the greenhouse effect and aerosol and cloud variations.
\end{abstract}

\section{INTRODUCTION}

In the present paper, the relationship of glacier mass balance to its environment is investigated solely based on observed information. The 20th century experienced significant climate change, which also had a profound impact on a number of terrestrial phenomena, such as vegetation (Schwarzenbach, 2000), surface hydrology (Brutsaert and Parlange, 1998) and cryosphere (Ohmura, 2004). During the 20th century a number of important observations were initiated that are ongoing. These observations make it possible to evaluate accurately the influence of climate change on glacier mass balance. In the present paper, glaciologically measured mass balance and meteorologically observed climatic elements are brought together, in order to evaluate quantitatively the weight of each climatic element in determining glacier mass balance. Five glaciers in Europe with long seasonal mass-balance observations were chosen. They are, in order of the length of the record: Claridenfirn, Switzerland; Storglaciären, Sweden; Storbreen, Norway; Glacier de Sarennes, France; and Vernagtferner, Austria. The climatic elements chosen are air temperature and solar radiation.

\section{IMPORTANCE OF SEASONAL MASS-BALANCE OBSERVATIONS}

Although mass balance has been observed for more than several years on over 100 glaciers, continuous records of $>30$ years are available only on about 60 glaciers. Winter and summer mass balances are measured only on about 30 of these glaciers. Among these, five glaciers have been selected which have especially long records of high quality. Separate observations of winter and summer mass balances are essential for investigating the effect of climate on glacier mass balance. Annual net mass balance is made up of the winter and summer mass balances. Except for glaciers near the equatorial and arid regions, winter mass balance is influenced largely by solid precipitation, while summer mass balance is largely determined by the melt. Solid precipitation and melt are quite different processes. Further, the former takes place mostly in winter, while the latter is a summer phenomenon. Therefore, having only annual mass balance is of little use if the objective is to investigate the processes between the climate and the mass balance.

Field conditions make it difficult to observe the seasonal mass balance on a long-term basis. Difficult conditions are met during the spring mass-balance observations that separate the annual mass balance into winter and summer mass balances. In some regions of the world the spring operation is nearly impossible due to the heavy accumulation that must be measured. It is hazardous to arrive at the glacier in regions of frequent avalanches. Therefore, one must bear in mind that existing seasonal mass-balance observations are made on glaciers that are easily manageable. The observations may be biased in favour of smaller glaciers with relatively small accumulation.

Since precipitation influences winter mass balance, climatic effects on winter mass balance necessitate a grasp of the time-space distribution of precipitation. This can best be obtained using a General Circulation Model (GCM) or global dataset such as high-resolution re-analyses. Summer mass balance, on the other hand, requires an understanding of the melt process, which requires information from local sources. In the present paper, priority is given to summer mass balance. The subject of winter mass balance or accumulation will be dealt with only when it is local information, such as stake-measured winter mass balance without going into precipitation physics. 
Table 1. Glaciers with winter $\left(B_{\mathrm{w}}\right)$ summer $\left(B_{\mathrm{s}}\right)$ and annual $\left(B_{\mathrm{n}}\right)$ mass-balance observations with $>30$ year records

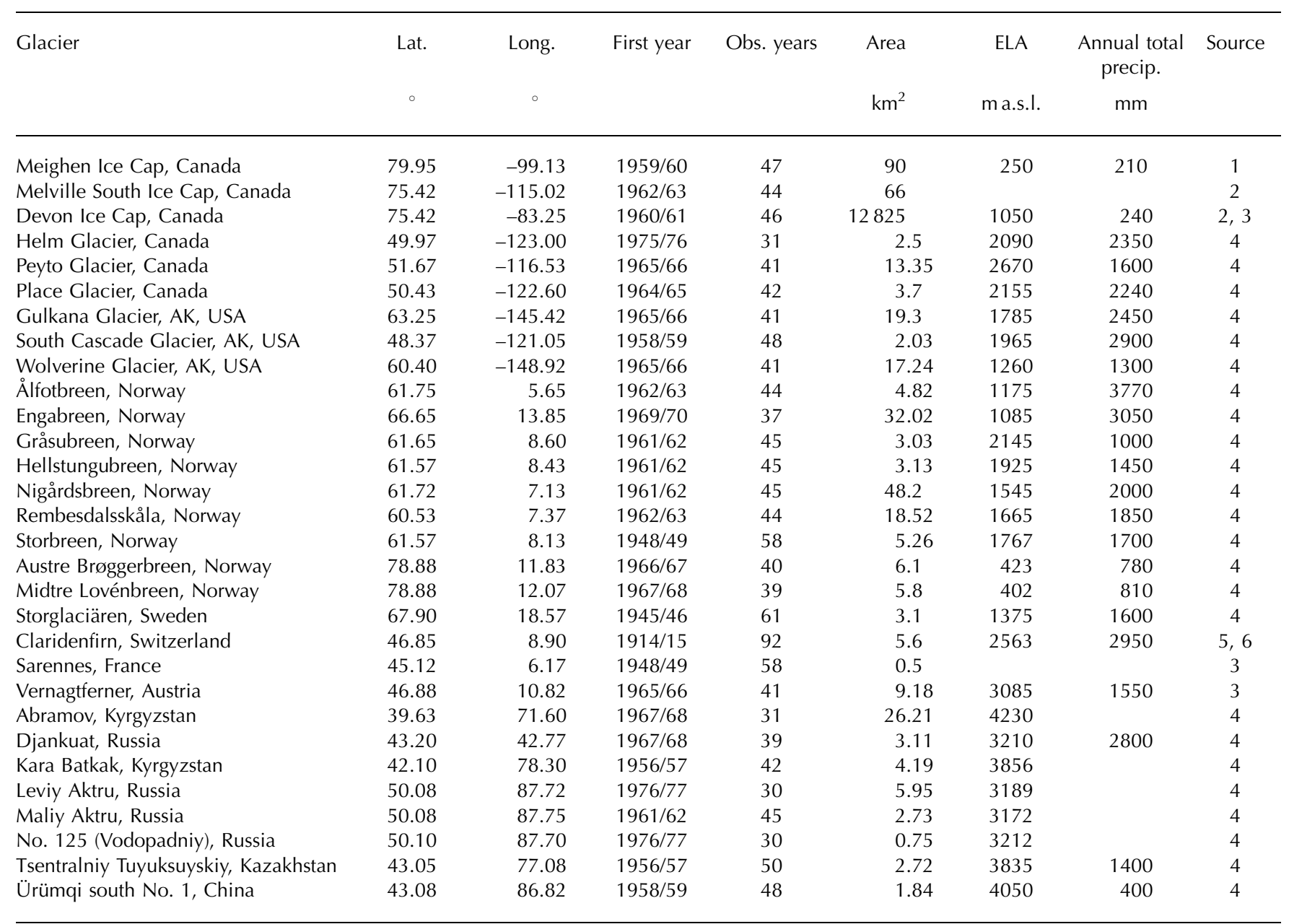

Notes: Vacant spaces are not available or are uncertain. ELA: equilibrium-line altitude.

Sources: 1. Taylor (1975); 2. Koerner (2002); 3. Haeberli and others (1998); 4. Ohmura and others (1992); 5. Müller and Kappenberger (1991); 6. Müller-Lemans and others (1997).

It is by now well established that melt is greatly influenced by air temperature. The dominance of air temperature in the melt stems from the fact that the largest energy source for melt is the terrestrial counter-radiation which is to a great extent a matter of temperature (Ohmura, 2001). The third largest energy source is usually sensible heat flux which is also a function of air temperature. In detail, however, temperature alone fails to explain the long-term variation of the melt. This is because the second largest heat source, solar radiation, also plays a role in the melt. In the following sections the relative importance of solar radiation for the melt will be clarified with respect to temperature.

\section{OBSERVED QUANTITIES AND DATA REDUCTIONS}

An observation period of 30 years is considered necessary for understanding the relationship between mass balance and climate. The 30 years since 1975 contain the last phase of the cooling period centred around 1970, and the subsequent modern warming phase. The main characteristics of the glaciers with $>30$ years of seasonal mass-balance observations are summarized in Table 1 . If the earlier mid-20thcentury warm spell is included, $>50$ years of observations are necessary. The regions with $>50$ years of observations are limited to Europe, and only four glaciers, Claridenfirn,
Storglaciären, Storbreen and Glacier de Sarennes, satisfy this condition. Vernagtferner, with a somewhat shorter observation period (41 years), was also included, as this addition makes the geographical sampling more complete, with glaciers from northern Scandinavia, southern Scandinavia, the western Alps and the eastern Alps.

The mass-balance observation on Claridenfirn was initiated by meteorologists from the Glaciology Commission of the Physics Society of Zürich. The original intention on Claridenfirn was to monitor meteorological precipitation rather than glaciological mass balance. Therefore, only two stakes were installed, both in the accumulation area. The Claridenfirn data were evaluated by Müller and Kappenberger (1991) from the period of the hydrological year 1914/15 up to $1983 / 84$. The observations and data evaluation for the subsequent years were maintained by the authors. The series on Glacier de Sarennes was started by Organisme des Eaux et Forêts, and continued by Cemagref. The annual and seasonal mass-balance data from 1948/49 to 1999/2000 are available from the World Glacier Monitoring Service (WGMS). The data for the later years are provided by C. Vincent of Laboratoire de Glaciologie et Géophysique de l'Environnement. The mass-balance observation on Storglaciären was initiated by W. Schytt and continued by the members of the Department of Physical Geography at Stockholm University. 


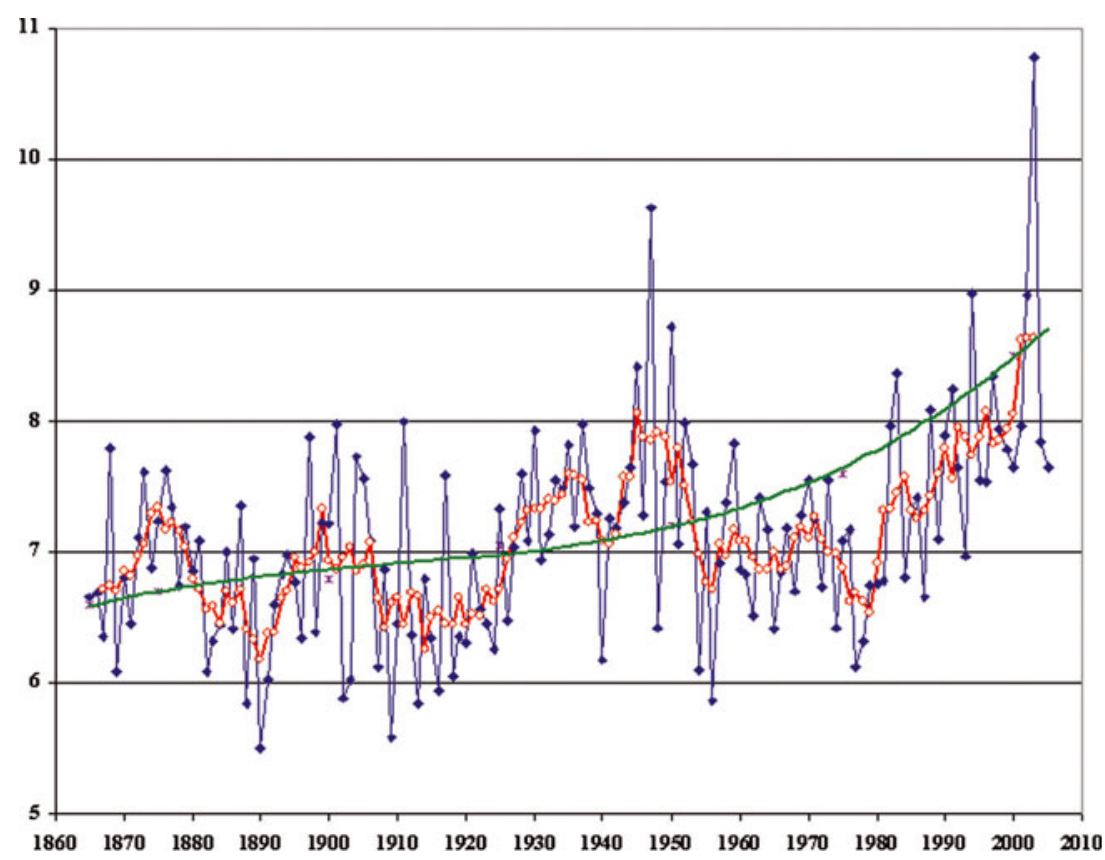

Fig. 1. Mean summer (JJA) air temperature for glacierized region of Europe during the last 150 years. The blue line indicates the mean of the three high-altitude stations in the Alps and Scandinavia (Säntis, Gran San Bernardo and Kjøremsgrende); the red line is the 5 year running mean. The green line is the simulation by ECHAM5-HAM T63 for the same region and same months with only greenhouse effect forcing. If the temperature change during the last 150 years had been caused solely by the enhanced greenhouse effect, the temperature history should have followed a similar course to the green curve. In reality, however, the temperature change had large decadal deviations above and below the green curve, including a powerful cooling after 1950, which cannot be explained by the greenhouse effect.

The mass-balance data up to $1999 / 2000$ are available in the Fluctuations of glaciers series. The data after 1999/2000 were provided by P. Jansson of Stockholm University. The Storbreen mass-balance observation was begun by O. Liestøl of the Norwegian Polar Institute (Andreassen, in press), and continued by G. Østrem and the members of the Norges Vassdrags- og Energiverk. The mass-balance-related information on the glaciers under this organization has been published annually in the Glaciological investigations in Norway series (previously, Glaziologiske undersökelser $i$ Norge) before it becomes available from WGMS. The mass balance on Vernagtferner in the Ötztalalpen in Austria was started in 1965 by O. Reinwarth of the Bavarian Academy of Sciences, and the data are available through WGMS up to 1999/2000. The data for the subsequent years are routinely published in the academy's annual reports. The massbalance series for Storglaciären, Storbreen, Glacier de Sarennes and Vernagtferner are considered to represent the entire glacier surface, while that for Claridenfirn is strongly biased towards the accumulation area.

Although the quality of these mass-balance series ranks with the best among the 30 observed glaciers, the number of glaciers selected is rather small. To test their representativeness, their mean annual net mass balance is compared to that of 20 other glaciers in Europe. These glaciers (with the starting hydrological years) are as follows: Allfotbreen (1962/63), Engabreen (1969/70), Gråsubreen (1961/62) Hellstungubreen (1961/62), Rembesdalsståka (1962/63) and Storbreen (1948/49) in Norway; Rabotsglaciären (1981/82) and Storglaciären (1945/46) in Sweden; Hintereisferner (1952/53), Kesselwandferner (1957/58), Sonnblickkees (1957/58) and Vernagtferner (1965/66) in Austria; Glacier de Sarennes (1948/49) and Glacier de Saint-Sorlin (1956/57) in France; Ghiacciaio del Caresér (1966/67) in
Italy; and Aletschgletscher (1922/23), Giresgletscher (1961/ 62), Limmerngletscher (1947/48), Plattalva (1947/48) and Silvretta (1959/60) in Switzerland. Sixteen of these glaciers have only annual net mass balance. They will be used to test how closely the mass balances of the four selected glaciers match the majority of these glaciers.

There were only two mass-balance observations during the early decades of the 20th century. The longer series, at Claridenfirn, had stakes only in the accumulation area, and so is suited only to investigating long-term trends in winter and summer mass balances, not to discussing the annual mass balance. The other series, at Aletschgletscher, is based on the hydrological balance method.

Air-temperature data are obtained from the following stations in Scandinavia and the Alps: Kjøremsgrende $(626 \mathrm{~m}$; starting in 1865) in Norway, and Säntis (2502 m; starting in 1864 ) and Gran San Bernardo (2479 m; starting in 1817) in the Alps. These stations are considered to be especially suited for the interpretation of the mass balance of glaciers in Europe with respect to glacier proximity and the length of observations. The mean air temperature for the summer months June-August (JJA) was calculated and is presented in Figure 1.

Solar radiation data are provided by the Global Energy Balance Archive (GEBA) which is part of the Baseline Surface Radiation Network (BSRN) archive. BSRN is a project of the World Climate Research Program (WCRP). GEBA contains presently about 260000 station month energy fluxes that are instrumentally measured at about 1600 sites. The most common flux archived in GEBA is solar radiation of a type called global radiation. Global radiation is the sum of direct solar and diffuse-sky radiation and approximates closely the incoming shortwave radiation on glaciers. There are about 1500 sites with global radiation 


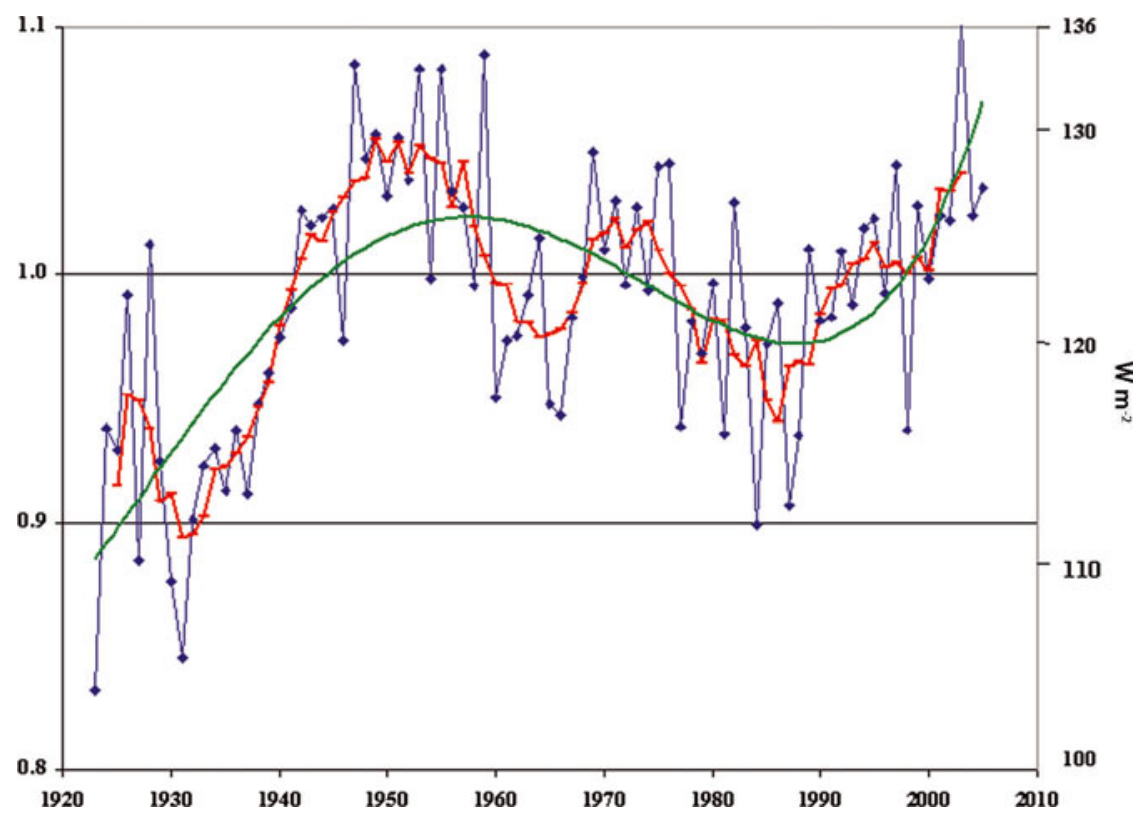

Fig. 2. Normalized mean global radiation for Europe during the last 80 years. The scale on the righthand side shows an approximate absolute value in $\mathrm{W} \mathrm{m}^{-2}$. The blue line is the mean of the world's longest observation series, Stockholm, Wageningen, Davos and Potsdam. The red line indicates the 5 year running mean, while the green line shows the best-fit third-order polynomial curve. The curve shows an early brightening to the 1950s, followed by the dimming trend to the late 1980s which is succeeded by the modern brightening.

archived in GEBA, from which the authors selected four stations - Stockholm, Wageningen, Davos and Potsdam that constitute the world's longest record of global radiation with very high quality. Since the beginning of the observation differs among the stations, and there is a latitudinal gradient in global radiation, the regional mean of Europe was computed after each station's data were normalized by the respective mean values for the common period of the observations, 1937-2005. The normalized regional mean global radiation is presented in Figure 2.

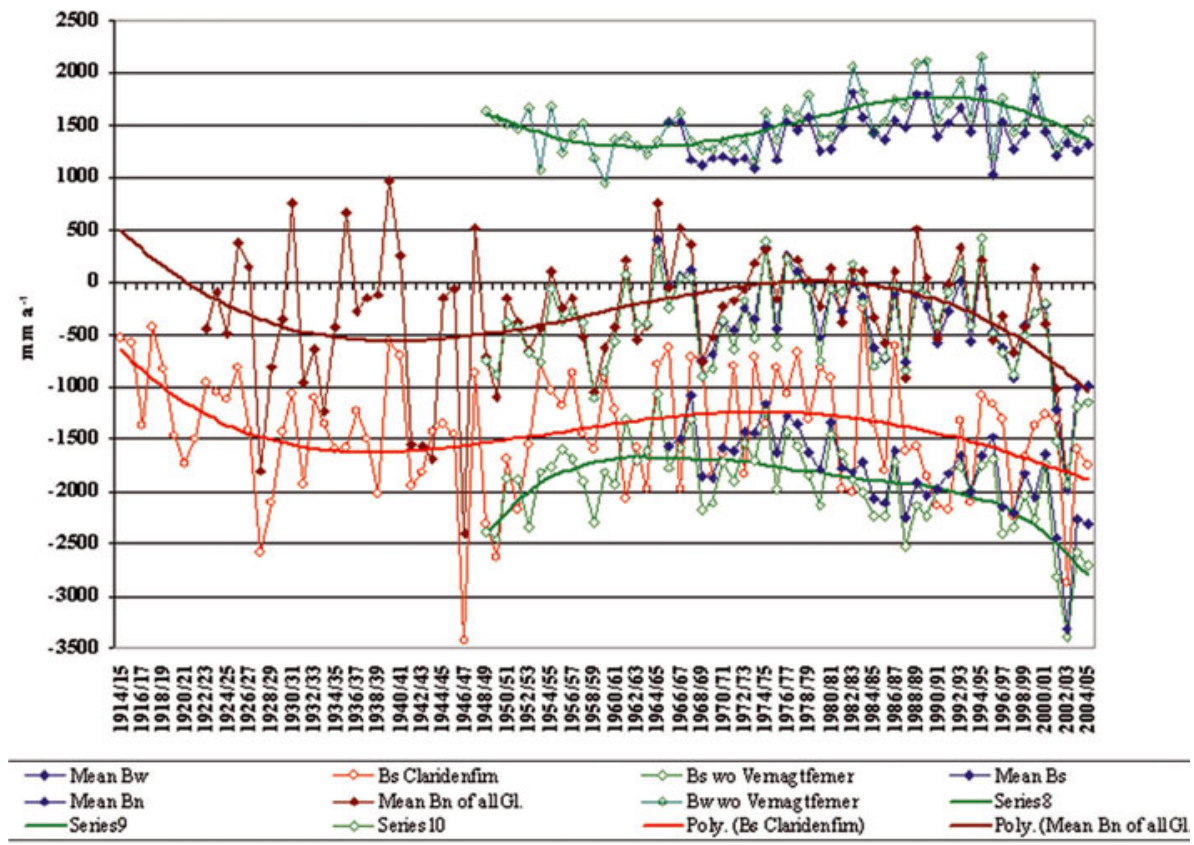

Fig. 3. Mean annual and seasonal mass balances on European glaciers. Lines at the top marked by diamonds represent winter mass balance, while those in the middle without markers show annual net mass balance. Three lines with open circles in the lower part of the figure are for summer mass balance. Blue lines are the means of Storglaciären, Storbreen, Glacier de Sarennes and Vernagtferner for the period 19652005. Green lines are the means of the first three glaciers, excluding Vernagtferner, representing the period 1948-2005. The brown line appearing only for the annual net mass balance is the mean of 20 glaciers in Europe, of which 16 have only the annual mass-balance observations. The early period prior to 1945 is represented only by Aletschgletscher. The red line with open circles represents summer mass balance for Claridenfirn. Being located in the accumulation area, the absolute amount of summer mass balance is smaller compared to other glaciers. The long-term trend of Claridenfirn, however, resembles those of other glaciers. 


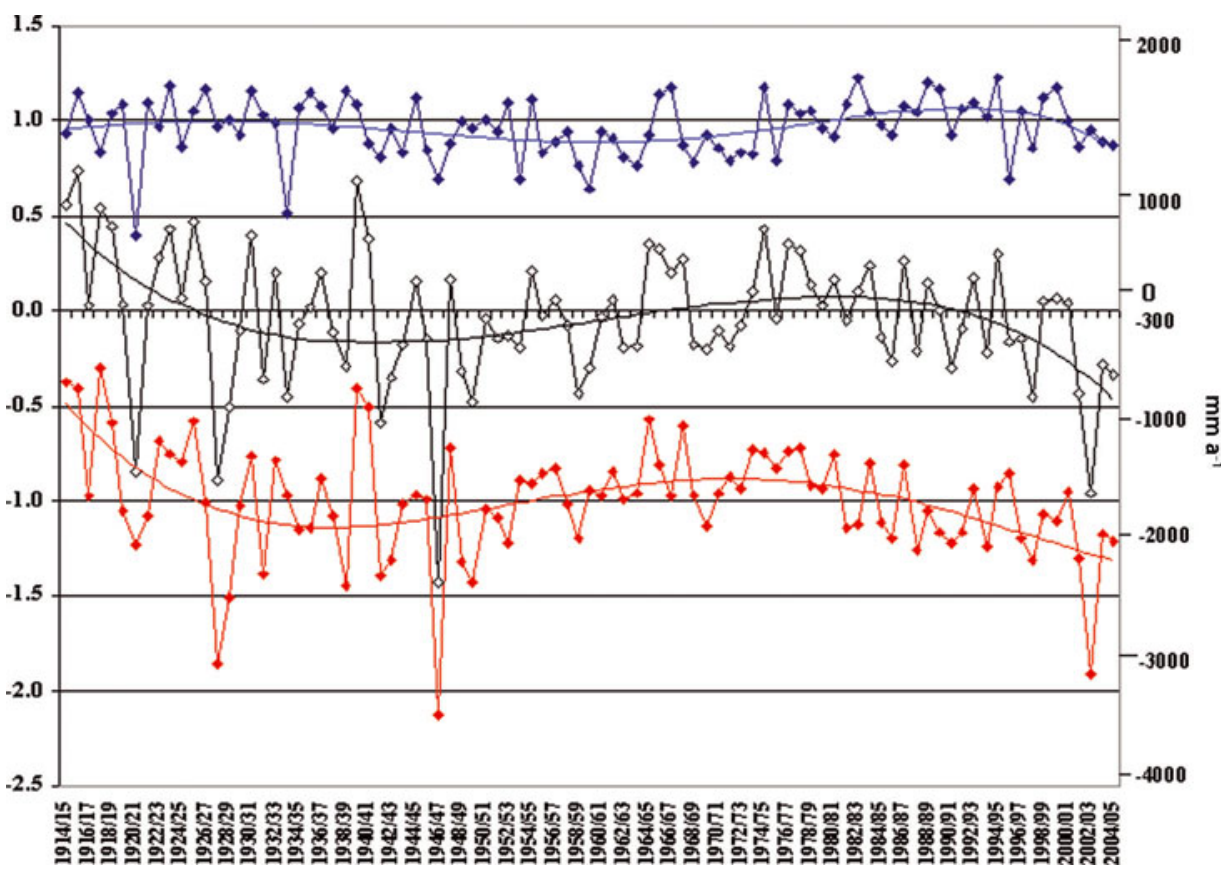

Fig. 4. Normalized mass balance of glaciers in Europe. The scale on the righthand side indicates approximate absolute values. The blue and red lines represent winter and summer mass balances, respectively. The black line in the middle is annual net mass balance. The method is suited to follow a regional trend of the area which has time series of different lengths covering different periods. The amplitude of the winter mass balance becomes exaggerated, as its mean value is smaller than that of the summer mass balance.

\section{MASS-BALANCE CHANGE DURING THE 20TH CENTURY}

The mean seasonal as well as annual mass balances for Storlaciären, Storbreen, Glacier de Sarennes and Vernagtferner are presented in Figure 3. The mean seasonal mass balances are calculated for two groups, one with all four glaciers and the other by excluding Vernagtferner. The latter contains 55 years of data, while the former provides only 41 years but with a better geographic coverage. The annual net mass balance is represented by three sets of data. The first is calculated with the four selected glaciers with 41 years of data (blue line). The second is the mean of the three longer series excluding Vernagtferner with 55 years of data (green line), and the third is with all 20 glaciers (brown line). The summer mass balance for Claridenfirn (red line) was added to compare with the mean summer mass balance of the three glaciers (green line). The most important finding of this analysis is the fact that the mean annual and seasonal mass balances calculated with the minimum three glaciers (green lines) closely resemble the trends calculated with all four glaciers. Further, the annual mass balance based on the three glaciers comes very close to the mean involving all twenty glaciers (brown line). Decadal variations of the seasonal and annual mass balances detected in the present study range from 500 to $1000 \mathrm{~mm} \mathrm{a}^{-1}$, which is one order of magnitude larger than the uncertainty of the mean specific mass balances in most observations evaluated by Funk (1985). These conditions justify the computation of the normalized mass balance for all glaciers involved in the present study with respect to their mean values as the base for normalization. The standard period is defined as the 40 years from 1965/66 to 2004/05, as all annual and seasonal mass balances of the four glaciers are observed without a missing year. The normalized winter, summer and annual mass balances are presented in Figure 4.
The 1910s and 1920s are characterized by a positive mass balance accompanied by a rather constant winter mass balance and a rapidly increasing melt. As a result, the annual mass balance became negative in the mid-1920s. During the subsequent 80 years it has continued to be negative, but with a rather complex history. The magnitude of the negative mass balance continued growing until the beginning of the 1940s. As more glaciers (Storglaciären, Storbreen and Sarennes) joined the list of mass-balance observations in the late 1940s, it was still strongly negative at about $-500 \mathrm{~mm}$. This trend of negative mass balance in the 1940s was caused by the large melt. It was, however, partly enhanced by a decreasing trend of winter accumulation that started in the early 1930s. After 1950 the mass clearly showed an increasing trend towards 1980 as the mass balance reached near-equilibrium for about a decade. This increasing trend lasted for 35 years from the late 1940s to the early 1980s. This tendency was caused by a clear decrease in melt until around 1970 and thereafter by an increasing winter accumulation. It is important to note that the mass balance was increasing towards 1980 even though the melt stayed constant already in the early 1970s. The annual mass-balance zero condition around 1980 was caused by an increase in winter accumulation that levelled off in the early 1990s. The mass balance turns clearly negative in the early 1990s as a result of increasing melt and decreasing winter accumulation. The absolute magnitude and the acceleration of the negative mass balance of the last 10 years are the largest in the entire observational period $\left(70 \mathrm{~mm} \mathrm{a}^{-2}\right)$.

The longest mass-balance observations captured an important course of variation, the initial decreasing trend in the early 20th century with the minimum around 1940 and the maximum around 1980 . Its range of fluctuation is about $600 \mathrm{~mm} \mathrm{a}^{-1}$. After 1998 the mass balance entered a period of unparalleled large loss. The ranges of variability for summer 


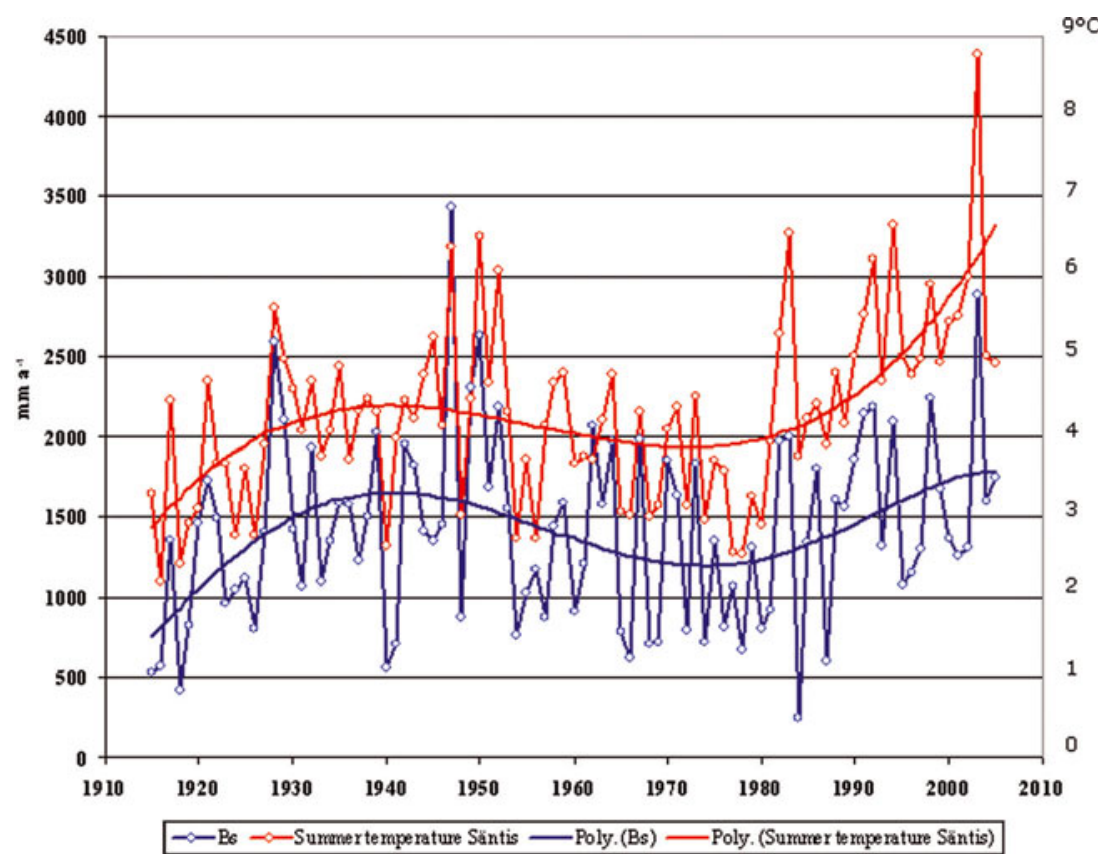

Fig. 5. Summer mass balance, $B_{\mathrm{s}}$ at Claridenfirn and summer three months (JJA) air temperature, $T$, at Säntis. The curves for $B_{\mathrm{s}}$ and $T$ are not parallel. While the last 10 years mean temperature is $1^{\circ} \mathrm{C}$ warmer than the decade around 1940 , the absolute value of the summer mass balance just matches the 1940s level.

and winter mass balances for the same period are 800 and $400 \mathrm{~mm} \mathrm{a}^{-1}$, respectively. The winter accumulation has been curtailed recently owing to the increase in air temperature.

\section{RELATIONSHIP TO CLIMATE CHANGE}

\section{Air temperature}

Figure 1 represents the air temperature for the glacierized region of Europe, showing a 20 year cold period during the 1910s and 1920s which indicates a warming trend starting in the late 1910s. This is when the oldest mass-balance observation started at Claridenfirn, showing a small ablation but an increasing trend. This warming tendency lasted till 1940 and coincides exactly with the point when the melt rate reached its peak. This agreement between long-term variations in temperature and summer mass balance is remarkable. The decline of the temperature from 1940 to the late 1970s is exactly reflected in the period of decreasing summer mass balance. The subsequent temperature increase starting in the late 1970s and continuing to the present matches the increase in summer ablation during the same period. Besides these long-term agreements between the temperature and ablation, the agreement in short-term variations is also remarkable. The warm summers of 1928, 1947, 1994 and 2003 all coincide with the years with exceptionally large melt. The cooler summers of 1918, 1940, 1955 and 1977 correspond to the years with smaller melt and positive annual mass balance. However, there is a shift in the relationship between the temperature and the summer mass balance over a long period. For example, the annual melt around 2000 is just about what was observed in 1950, although the present temperature is clearly higher than that in 1950. Taking individual years, the all-time maximum melt was observed in the summer of 1947, which also made 1946/47 the hydrological year with the record loss. Both summer and annual mass balance showed $>500 \mathrm{~mm}$ loss in comparison with the warmest summer of
2003. The summer of 1928 produced an equivalent melt to 2003 under a temperature $>3{ }^{\circ} \mathrm{C}$ cooler. In general, if the temperature was the same, more melt occurred in the earlier 20th century than in the later period after 1970. This situation makes one wonder if solar radiation changed during the same period and influenced the ablation.

\section{Global radiation}

The fact that global radiation in Europe showed a substantial change over the course of the 60 years between the $1920 \mathrm{~s}$ and 1980 s by a range of almost $20 \mathrm{~W} \mathrm{~m}^{-2}$ was first reported by Ohmura and Lang (1989). This finding was duplicated later by Liepert and others (1994). Subsequently, it was also found that the long-term variation of about $10 \mathrm{~W} \mathrm{~m}^{-2}$ indeed occurred globally (Stanhill and Moreshet, 1992). In Europe, global radiation generally increased from the beginning of the observation in the early 1920s until the 1950s when it reached the century's highest value. The increase during this period is $20 \mathrm{~W} \mathrm{~m}^{-2}$. After the late $1950 \mathrm{~s}$, global radiation decreased for 30 years until the late 1980s. The decrease observed during this period is $10 \mathrm{~W} \mathrm{~m}^{-2}$. During the last 15 years, global radiation has recovered somewhat, but without reaching the 1950 s level. The decreasing phase from the mid-1950s to the mid-1980s subsequently became known as 'global dimming', and the increasing phase after the 1980s as 'global brightening'. This long-term variation of global radiation is explained by the direct and indirect radiative effects of aerosol (Ohmura, 2006). The decadal means of global radiation are 129, 119 and $123 \mathrm{~W} \mathrm{~m}^{-2}$, respectively, for the peak period of the 1950s (1949-59), the darkest period of dimming (1977-87) and the recovering last 10 years (1996-2005). These decadal variations in solar radiation are larger than the expected increase in terrestrial counter-radiation of $4 \mathrm{~W} \mathrm{~m}^{-2}$ by doubling $\mathrm{CO}_{2}$, and must have a profound effect on glacier melt. This analysis requires a set of data on mass balance, temperature and radiation, obtained in close proximity to each other. Claridenfirn was 


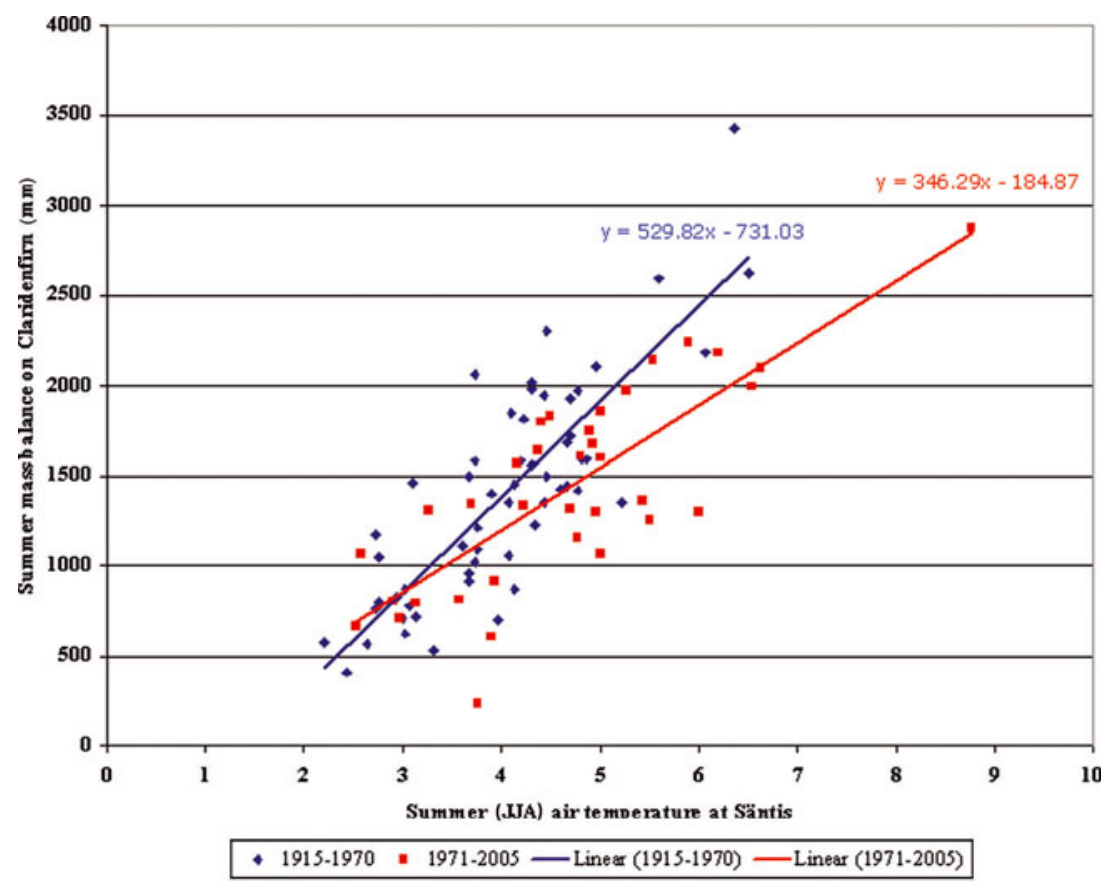

Fig. 6. The relationships between the summer mass balance and summer temperature (JJA) before and after 1970. Under the same temperature the mass loss was larger in earlier times.

chosen as the site for a pilot study for the relationships among these three elements, as it has Säntis and Davos nearby where air temperature and global radiation are observed within $80 \mathrm{~km}$.

\section{Long-term melt on Claridenfirn}

Summer mass-balance measurement on Claridenfirn has been carried out since 1915, giving 91 years of continuous observations. The Säntis meteorological observatory, which is located at $2502 \mathrm{ma}$ a.s.l., corresponding to the long-term equilibrium-line altitude of Claridenfirn, has continuous meteorological records since 1864. The Davos physical and meteorological observatory has kept detailed radiation measurements since the beginning of the 20th century, including global radiation starting in 1935.

In the course of the last 90 years, the decadal mean of summer ablation has increased from about 1285 to $1550 \mathrm{~mm} \mathrm{a}^{-1}$, at a rate of $2.9 \mathrm{~mm} \mathrm{a}^{-2}$ as presented in Figure 5. The actual course of the change, however, is not a simple monotonic function but resembles a wave function with 70 year period overlapping an increasing trend. During the 1910s when the mass-balance measurement started, the smallest mean ablation was about $1000 \mathrm{~mm} \mathrm{a}^{-1}$, but with an increasing trend. From 1930 to 1955, the summer mass balance was above average, with its peak around 1940 at $1600 \mathrm{~mm} \mathrm{a}^{-1}$. This declined thereafter, with a minimum ablation of $1200 \mathrm{~mm} \mathrm{a}^{-1}$ in the mid-1970s. During the past 30 years, the ablation has recovered gradually, in the early 2000 s reaching about the same level as in the 1940s. If one looks only at the phase of this fluctuation, the ablation curve coincides very well with the temperature curve of the 20th century. The group with the largest ablation, however, appears in the 1940s and early 1950s, and not in the last decade as the temperature reached the century's maximum. Quantitatively, the mean ablation during the 1940s was $1800 \mathrm{~mm} \mathrm{a}^{-1}$, under a summer mean temperature of $4.7^{\circ} \mathrm{C}$, while the last decade saw a mean ablation of $1600 \mathrm{~mm} \mathrm{a}^{-1}$ under a much higher temperature of $5.6^{\circ} \mathrm{C}$. Looking at individual years, Europe's record warmest summer of 2003 $\left(8.8^{\circ} \mathrm{C}\right)$ gave only $2880 \mathrm{~mm}$ ablation, $500 \mathrm{~mm}$ less than the summer of $1947\left(6.4^{\circ} \mathrm{C}\right)$ with a $>2^{\circ} \mathrm{C}$ cooler summer temperature. Ablation in the world's hottest year of 1998 lagged behind that of 1950 by $400 \mathrm{~mm}$. This indicates that the earlier warm period around 1940 had an additional energy source that is lacking in the present warm period. In Figure 6 the relationship between summer mass balance and temperature is presented for each year in two groups, before and after 1970, regarding 1970 as the year dividing the earlier sunnier and later darker periods of the last 70 years. Between these groups, there is a difference in mean ablation of $243 \mathrm{~mm}$. The ablation difference corresponds to $80 \mathrm{MJ} \mathrm{m}^{-2}$, which, averaged over the 3 months, is $10 \mathrm{~W} \mathrm{~m}^{-2}$. The global radiation difference for the periods before and after 1970 is $15 \mathrm{~W} \mathrm{~m}^{-2}$, which corresponds to about $10 \mathrm{~W} \mathrm{~m}^{-2}$ after the mean albedo of the melting period, 0.4 , is taken into account. This analysis shows that changes in global radiation indeed left a trace on the long-term summer ablation observed on Claridenfirn. A multivariate regression plane among the summer mass balance, summer temperature and summer global radiation was calculated with the following result: $B_{\mathrm{s}}=370 T+15 R-3584$, where $B_{\mathrm{s}}$ is the summer mass balance on Claridenfirn in $\mathrm{mma}^{-1}, T$ is the mean air temperature in ${ }^{\circ} \mathrm{C}$ at Säntis for JJA, and $R$ is the mean global radiation in $\mathrm{W} \mathrm{m}^{-2}$ for the same months at Davos. From this relationship, one obtains the following difference equation: $\Delta B_{\mathrm{s}}=370 \Delta T+15 \Delta R$, where $\Delta$ stands for the range of variation. Over the last 70 years since 1935 , temperature and global radiation varied on a decadal basis by $2.6^{\circ} \mathrm{C}$ and $25 \mathrm{~W} \mathrm{~m}^{-2}$, respectively. During the same period the summer ablation increased by $210 \mathrm{~mm}$ with a 70 year fluctuation whose amplitude was $200 \mathrm{~mm}$. The form of the above regression plane and the ranges of the temperature and radiation variability allow one to conclude that the variation of global radiation caused $28 \%$ of the entire change in 
summer ablation, while the remaining $72 \%$ is due to temperature change. Vincent (2002) reports that $>60 \%$ of the summer ablation on four French glaciers was due to temperature change. The unprecedented mass loss of the last 15 years is caused by a combination of the ongoing enhanced greenhouse effect of terrestrial radiation and the global brightening of solar radiation that started in the late 1980s.

\section{CONCLUSION}

The analysis based on four long-term annual and seasonal mass-balance records and sixteen additional annual net mass-balance only observation series shows that the annual net mass balance of glaciers in Europe was very likely positive at the beginning of the 20th century. It turned negative in the mid-1920s for the next 80 years. The annual mass balance reached a minimum around 1940, and then recovered towards 1980, when the glaciers were almost at equilibrium for about 10 years. The mass loss began in the late 1980 s and has accelerated to the present. The acceleration of the net loss during the last 10 years (19952005 ) is $70 \mathrm{~mm} \mathrm{a}^{-2}$, and at the end of the 20th century the annual mass balance entered the era of the largest loss of the century, culminating in $1050 \mathrm{~mm} \mathrm{a}^{-1}$ in the 2004/05 balance year. The decadal change in mass balance is more influenced by the change in summer mass balance. The change in summer mass balance is regulated to $72 \%$ by air temperature, but the remaining $28 \%$ is steered by variations in global radiation which are affected by the change in aerosol content of the atmosphere. Glacier variations registered the effects of increasing temperature and fluctuating solar global radiation in the course of the 20th century, clearly reflecting the consequences of the enhanced greenhouse effect and the aerosol changes.

\section{ACKNOWLEDGEMENTS}

The authors are indebted to a number of individuals and organizations who assisted the present work. In particular, thanks are due to W. Haeberli, M. Hoelzle and M. Zemp of the World Glacier Monitoring Service, Zurich, P. Jansson of Stockholm University, C. Vincent of the Laboratoire de Glaciologie et Géophysique de l'Environnement, Grenoble, and $\mathrm{H}$. Escher-Vetter and L. Braun of the Bavarian Academy of Sciences for providing pre-publication data of mass balance; K. Behrens of the German Weather Service, Lindenberg, and B. Heusinkveld of Wageningen University for providing recent radiation data for Potsdam and Wageningen, respectively; P. Jansson for Swedish meteorological data and Ø. Nordli of the Norwegian Meteorological Institute for Norwegian meteorological data; and M. Jackson of the Norwegian Water Resources and Energy Directorate for information on the history of glacier observations in
Norway. The results of the GCM experiments were compiled by M. Wild and P. Tschuck at ETH Zürich. The present work was financed through a grant for the project Long-term variations of radiation, by the Swiss National Science Foundation.

\section{REFERENCES}

Andreassen, L.M., H. Elvehøy, B. Kjøllmoen, M. Jackson and R. Engeset. In press. Long term observations of glaciers in Norway. Proceedings of Workshop on Mountain Glacier and Society, 4-6 October, 2006, Wengen, Switzerland.

Brutsaert, W. and M.B. Parlange. 1998. Hydrologic cycle explains the evaporation paradox. Nature, 396(6706), 30.

Funk, M. 1985. Räumliche Verteilung der Massenbilanz auf dem Rhonegletscher und ihre Beziehung zu Klimaelementen. Zürcher Geogr. Schr. 24.

Haeberli, W., M. Hoelzle, S. Suter and R. Frauenfelder, comps. 1998. Fluctuations of glaciers 1990-1995 (Vol. VII). Wallingford, Oxon., IAHS Press; Nairobi, UNEP; Paris, UNESCO.

Koerner, R.M. 2002. Glaciers of the High Arctic islands. In Williams, R.S. and J.G. Ferrigno, eds. Satellite image atlas of glaciers of the world. US Geol. Surv. Prof. Pap. 1386-J, J111-J146.

Liepert, B., P. Fabian and H. Grassel. 1994. Solar radiation in Germany - observed trends and an assessment of their causes. Part 1: regional approach. Beitr. Phys. Atmos., 67(1), 15-29.

Müller, H. and G. Kappenberger. 1991. Claridenfirn-Messungen 1914-1984: Daten und Ergebnisse eines gemeinschaftlichen Forschungsprojektes. Zürcher Geogr. Schr. 40.

Müller-Lemans, H., M. Aellen, L.N. Braun, G. Kappenberger and U. Steinegger. 1997. Niederschlagsverteilung im Tödigebiet: Messungen und Überprüfung mit der Wasserhaushaltsgleichung. Beitr. Hydrol. Schweiz 36, 7-43.

Ohmura, A. 2001. Physical basis for the temperature-based meltindex method. J. Appl. Meteorol., 40(4), 753-761.

Ohmura, A. 2004. Cryosphere during the twentieth century. In Sparling, J.Y. and C.J. Hawkesworth, eds. The state of the planet: frontiers and challenges in geophysics. Washington DC, American Geophysical Union, 239-257.

Ohmura, A. 2006. Observed long-term variations of solar irradiance at the Earth's surface. Space Sci. Rev., 125(1-4), 111-128.

Ohmura, A. and H. Lang. 1989. Secular variation of global radiation in Europe. In Lenoble, J. and J.F. Geleyn, eds. IRS '88: Current Problems in Atmospheric Radiation. Hampton, VA, A. Deepak Publishing, 298-301.

Ohmura, A., P. Kasser and M. Funk. 1992. Climate at the equilibrium line of glaciers. J. Glaciol., 38(130), 397-411.

Schwarzenbach, F.H. 2000. Altitude distribution of vascular plants in mountains of East and Northeast Greenland. Medd. Grønl. Biosci. 50.

Stanhill, G. and S. Moreshet. 1992. Global radiation climate changes: the world network. Climatic Change, 21(1), 57-75.

Taylor, B. 1975. The energy balance climate of Meighen Ice Cap, N.W.T. Vol. 2. Ottawa, Ont., Polar Continental Shelf Project.

Vincent, C. 2002. Influence of climate change over the 20th century on four French glacier mass balances. J. Geophys. Res. 107(D19), 4375. (10.1029/2001JD000832.) 